\title{
Diagnostic Evaluation of Immunoassay Kits for Early Pregnancy Detection in Cattle
}

\author{
Amit Khatti ${ }^{1}$, Vinothini Prabhakaran ${ }^{1}$, Nitish Singh Kharayat ${ }^{2}$, Priya Ranjan Kumar ${ }^{3}$, Manas Kumar Patra ${ }^{1}$, \\ K Narayanan ${ }^{4}$, Harendra Kumar ${ }^{1}$ and Sanjay Kumar Singh ${ }^{1^{*}}$ \\ ${ }^{1}$ Division of Animal Reproduction, ICAR-Indian Veterinary Research Institute, Izatnagar, Bareilly, U.P., INDIA \\ ${ }^{2}$ Division of Temperate Animal Husbandry, ICAR-Indian Veterinary Research Institute, Mukteshwar, Uttarakhand, INDIA \\ ${ }^{3}$ Department of Veterinary Gynaecology E Obstetrics, FVAS, RGSC-Banaras Hindu University, Banaras, INDIA \\ ${ }^{4}$ ICAR-Indian Veterinary Research Institute, Bengaluru, INDIA \\ *Corresponding author: SK Singh; E-mail: singhsanjayk69@gmail.com
}

Received: 04 Jan., 2020

Revised: 08 Feb., 2021

Accepted: 08 Feb., 2021

\begin{abstract}
Diagnosis of pregnancy at an early stage is important for profitable dairy enterprise. The objective of present study was to evaluate diagnostic performance of immunoassay kits used for early pregnancy detection in cattle. Two ELISA based kits were used for detection of pregnancy-associated glycoproteins-1 (PAG-1) and pregnancy-specific protein B (PSP-B). Another RIA based kit was used for the estimation of serum progesterone $\left(\mathrm{P}_{4}\right)$. Ultrasound examination was done in all cows under controlled experimental conditions and used as a reference method. Based on availability of assay points, two pregnant groups of dairy cattle i.e. 30-35D $(\mathrm{n}=16)$ and 45-50D $(\mathrm{n}=10)$ were included for PAG-1/PSP-B estimation. However, all four Pregnant groups viz., 7-10D (n=11), 17-20D (n=8), 30-35D $(n=16)$ and 45-50D $(n=10)$ and three non-pregnant groups viz., Heifer $(n=6)$, Cyclic Non-AI ( $n=13$ ) and Post-partum (PP; $n=13)$ were included for progesterone estimation. Ultrasound examination was done at 3035D and 45-50D of pregnancy to screen the experimental animals and early pregnancy samples were confirmed retrospectively. Sensitivity of all three immunoassay kits for PAG-1, PSP-B and $\mathrm{P}_{4}$ was reported $92.31 \%, 96.15 \%$ and $84.44 \%$, respectively. Specificity, positive predictive value (PPV), negative predictive value (NPV) and Accuracy for P4 kit were observed 90.63\%, $0.93,0.81$ and $87.01 \%$, respectively. However, lack of values in non-pregnant animals in study for the estimation of PAG-1/ PSP-B limits full reflection of diagnostic performance of respective kits. Henceforth, it is recommended to include large number of pregnant as well as non-pregnant animals to conclude comprehensively on the diagnostic performance of these assays.
\end{abstract}

\section{HIGHLIGHTS}

(0 ELISA kits based on PAG-1/PSP-B protein showed comparable sensitivity to screen the pregnant animals.

( RIA kit based on progesterone estimation showed better diagnostic values viz., sensitivity, specificity, PPV, NPV and accuracy for pregnancy detection in dairy cattle.

Keywords: ELISA/RIA, PAG-1/PSP-B, Pregnant, Non-pregnant, Progesterone, Ultrasound

Diagnosis of pregnancy at an early stage is important for efficient reproductive management in dairy cattle. The commonly available clinical methods for pregnancy diagnosis in cattle are per-rectal palpation of the genital organs and ultrasonography (Zemjanis, 1970; Thompson et al., 1994; Ginther, 1998; Fricke, 2002). Over the years, emphasis has been given to develop laboratory based methods of early pregnancy diagnosis in bovine, which evolved many assays based on the estimation of hormones and pregnancy specific protein/antigens in the blood. The possibility of using progesterone $\left(\mathrm{P}_{4}\right)$ for pregnancy diagnosis in farm animals was proposed in 1971 by

How to cite this article: Khatti, A., Prabhakaran, V., Kharayat, N.S. Kumar, P.R., Patra, M.K., Narayanan, K., Kumar, H. and Singh, S.K. (2021). Diagnostic evaluation of immunoassay kits for early pregnancy detection in cattle. J. Anim. Res., 11(1): 25-32.

Source of Support: None; Conflict of Interest: None 
Laing and Heap (Rioux and Rajotte, 2004) and further its quantification could help in pregnancy diagnosis as early as 21-24 days after breeding (Fricke et al., 2016). This has led to development of several commercial kits based on Radio Immunoassay (RIA) or Enzyme linked Immunosorbent Assay (ELISA) methods (Sah et al., 2017). The progesterone is most biologically active progestogen in cattle and primarily produced by the corpus luteum (CL) during the estrous cycle and by the CL as well as placenta during pregnancy. Further, blood based pregnancy-specific assay was developed by estimating pregnancy-specific protein B (PSP-B) or Pregnancy-associated glycoproteins (PAGs, Sasser et al., 1986; Humblot et al., 1988; Zoli et al., 1992; Vasquez et al., 1995) in dairy cattle around 2130 days after artificial insemination (AI).

Pregnancy-associated glycoproteins belong to a large family of aspartic peptidases, of which pregnancy-specific protein B was the first member to be discovered (Butler et al., 1982). These glycoproteins are produced by specialized trophoblastic cells in the ruminant placenta (Eckblad et al., 1985; Resee et al., 2016), which migrate from the trophectoderm to fuse with maternal uterine epithelial cells, and release their granular content containing PSP-B/ PAG into the maternal circulation (Wooding, 1992). Blood concentrations of PAGs were initially measured by RIA (Humblot et al., 1988; Zoli et al., 1992; Szenci et al., 1998; Ayad et al., 2007). More recently, ELISA based assays for the estimation of PSP-B (Gabor et al., 2007; Romano and Larson, 2010) and PAG (Friedrich and Holtz, 2010; Commun et al., 2016) became commercially available under various trade names viz., BioPRYN, IDEXX, QuickVET etc., which provide a qualitative pregnancy classification based on measurement of PSP-B and PAG in the serum of pregnant ruminants. The information on the use of these immunoassays under field conditions is very meager. Therefore, the objective of the present study was to evaluate diagnostic ability of some commonly available ELISA kits viz., PSP-B (Biospes), PAG-1 (Biospes) and progesterone (Immunotecch) for pregnancy determination in dairy cattle using trans-rectal ultrasound as a reference method.

\section{MATERIALS AND METHODS}

The present study was a part of DBT funded project "Development of early pregnancy diagnostic assay through discovery of biomarkers in cattle and Buffalo." Approval from IAEC has been granted prior to study on experimental animals.

\section{Experimental design}

The study was conducted on the cattle $(n=77)$ of different breeds (Sahiwal, Tharparkar and Crossbreds) which included pregnant $(n=45)$ and non-pregnant $(n=32)$ cattle. Pregnant animals were further divided into four groups i.e. 7-10D ( $\mathrm{n}=11), 17-20 \mathrm{D}(\mathrm{n}=8), 30-35 \mathrm{D}(\mathrm{n}=16)$ and 45-50D $(n=10)$. Non-pregnant animals included i.e. Heifer $(n=6)$, Cyclic Non-AI ( $n=13)$ and Post-partum (PP; n=13).

Pregnancy was determined by tans-rectal ultrasound on two occasions i.e. about $30 \mathrm{D}$ and $45 \mathrm{D}$ post $\mathrm{AI}$ using $7.5 \mathrm{MHz}$ linear probe through trans-rectal real time $\mathrm{B}$ mode USG (EXAGO ECM ${ }^{\mathrm{TN}}$, France), while it was retrospectively confirmed in 7-10D and 17-20D groups in pregnant cattle.

\section{Blood sampling}

Blood samples were collected aseptically from the both pregnant and non-pregnant cattle of C\&B Farm, ICARIVRI, Izatnagar and other dairy farms including field samples. Approximately, 5-7 $\mathrm{ml}$ of blood from each selected cattle was collected by jugular venipuncture in vacutainers containing clot activator. The vacutainers containing blood sample were kept at $37^{\circ} \mathrm{C}$ for coagulation of blood. The sera were separated by centrifugation at $800 \times \mathrm{G}$ for 15 minutes. The serum samples were labeled properly and stored at $-20^{\circ} \mathrm{C}$ till use.

\section{Estimation of serum PAG-1 and PSP-B}

Serum samples were assayed for PAG-1 (Biospes; Lot no.: E06d/2020M) and PSP-B (Biospes; Lot no.: E06e/2020M) using two different ELISA kits (Chongquing Biospes Co. Ltd, China) according to manufacturer's instructions. PAG-1 and PSP-B estimations were done only in two groups of pregnant animals i.e. $30-35 \mathrm{D}(\mathrm{n}=16)$ and 45 $50 \mathrm{D}(\mathrm{n}=10)$, based on the availability of the assay points. Reading in terms of optical density (OD) for all the test samples and provided standards were taken at $450 \mathrm{~nm}$ in multimode plate reader (Biorad, Imark, USA). The sensitivities of the kits were 1.0 and $0.3 \mathrm{ng} / \mathrm{ml}$ for PAG1 and PSP-B protein, respectively. Relative OD was 
calculated for each well through provided formula in instruction manual and subsequently standard curve was generated for both the kits (Fig.1). Concentration of PAG1 and PSP-B were determined using equation of standard curve and eventually pregnancy status was determined for each sample.
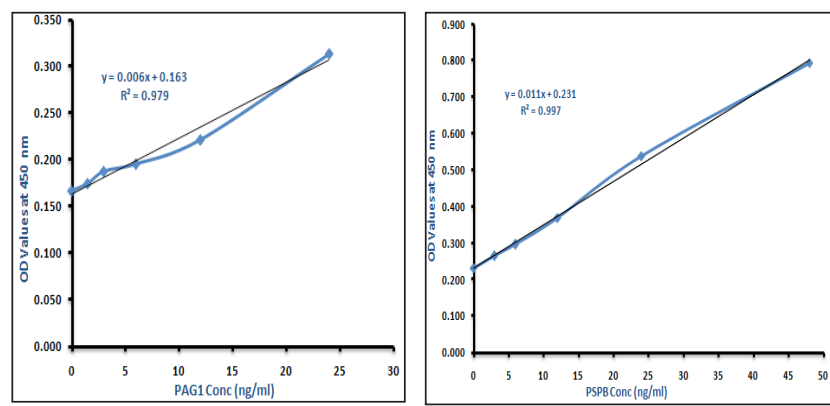

Fig. 1: Standard curve for ELISA kits of PAG-1 and PSP-B based on optical density of sera samples at $450 \mathrm{~nm}$

\section{Estimation of progesterone concentration}

Progesterone concentrations in the sera were estimated by RIA using standard diagnostic kits (Immunotech, France). Progesterone estimation was done adopting the procedure described by the manufacturer. The radioactive count of all tubes measured in the gamma counter (Packard Cobra II Gamma Counter) calibrated for $\mathrm{I}^{125}$ for one minute and programmed to evaluate the concentration of progesterone in the serum samples from the standard curve drawn using values of known standards. The values were obtained in $\mathrm{ng} / \mathrm{ml}$. The analytical sensitivity of the kit was $0.05 \mathrm{ng} / \mathrm{ml}$ and the intra-assay and inter-assay coefficients of variation were d" $6.5 \%$ and d" $7.2 \%$, respectively.

\section{Ultrasound examination}

Ultrasonographic (USG) examination was done to screen pregnant and non-pregnant animals. Embryonic vesicle, conceptus, embryonic membranes and embryonic fluid were observed to confirm the pregnancy, while empty uterine horns with rosette shape structure in cross-section or empty tube-like structure in longitudinal section were appreciated to confirm the non-pregnancy in experimental cattle (Fig. 2). Animals were considered doubtful, if failed to appreciate any of mentioned ultrasound features and the particular animal was not included in the study.
Further, early pregnant groups (7-10D and 17-20D) were confirmed retrospectively through USG and animals found non-pregnant were dropped from the study groups. The accuracy of pregnancy diagnosis through ultrasound examination may be considered $100 \%$ in controlled experimental conditions (Szenci et al., 1995) and therefore used as a reference method in the present study with $100 \%$ sensitivity and specificity.

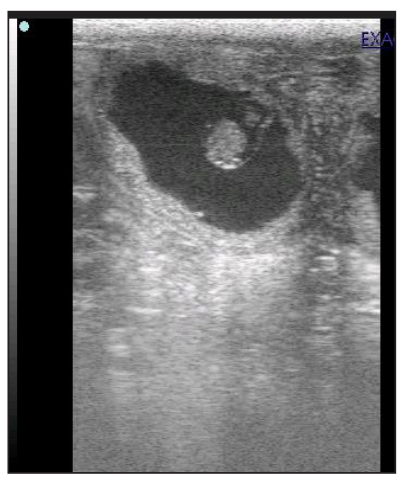

(A)

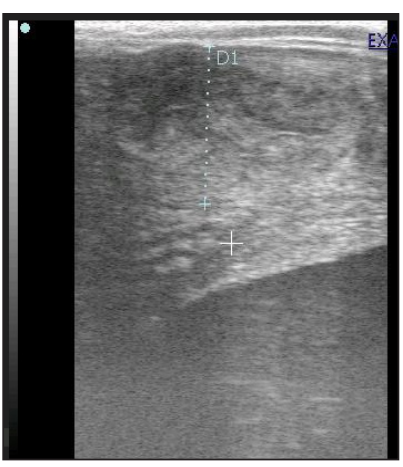

(C)

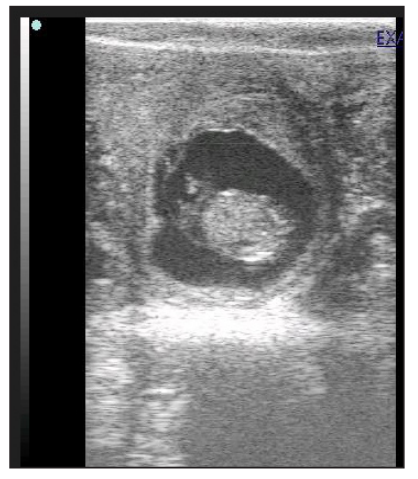

(B)

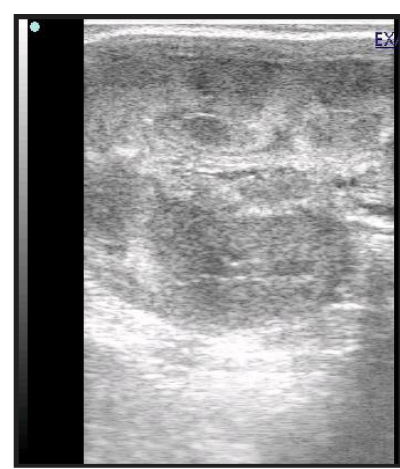

(D)
Fig. 2: Ultrasound examination of pregnant $(A, B)$ and nonpregnant $(\mathrm{C}, \mathrm{D})$ animals. (A,B) Conceptus with embryonic vesicle and fluid is visible at 30 and 45 day post-breeding, respectively, (C) Cross-section of both empty uterine horns is visible in Non-AI cattle in circular rosette shape fashion, (D) longitudinal section of both empty uterine horns is visible in non-pregnant cow

\section{Comparative assessment of diagnostic performance}

Assessment of comparative diagnostic evaluation of three immunoassay kits was done for early pregnancy diagnosis using USG as reference method having ideal sensitivity and specificity of $100 \%$. Cut-off value was decided for 
three assays to categorize the result into pregnant and non-pregnant animals. ROC curve (AUC: 0.929) was generated for data of serum progesterone and $4.82 \mathrm{ng} /$ $\mathrm{ml}$ concentration was decided as cut-off value through obtaining point farthest to $\mathrm{x}$-axis and nearest to $\mathrm{y}$-axis. ROC curve for other two biomarkers PAG-1 and PSP-B could not be generated as the values for non-pregnant groups were not available. Therefore, cut-off value to discriminate pregnant and non-pregnant was decided using available literature (Sasser et al., 1986; Piechotta et al., 2011). Cut-off value was 1.5 and $1.0 \mathrm{ng} / \mathrm{ml}$ for PAG-1 and PSP-B, respectively. Subsequently, true positive, false negative, true negative and false positive samples were screened based on cut off value for these immunoassay kits, eventually diagnostic parameters such as sensitivity $(\mathrm{Sn})$, specificity (Sp), positive predictive value (PPV), negative predictive value (NPV), accuracy and Youden's Index (J) were calculated to interpret comparative diagnostic performance using USG as reference method.

\section{STATISTICAL ANALYSIS}

The data generated in the present study for assessment of pregnancy status was analyzed by one way ANOVA using GraphPad Prism version 8.0.2 and receiver operating characteristic (ROC) curve using SPPS software package for windows (SPSS-20). A probability value of $\mathrm{P}<0.05$ indicated that the difference was statistically significant while $\mathrm{P}>0.05$ indicated that difference was not significant.

\section{RESULTS AND DISCUSSION}

\section{Serum PAG-1/PSP-B}

The mean \pm SEM concentrations of PAG-1 and PSP-B proteins in serum samples of cattle in the two pregnant groups (30-35D and 45-50D) are presented in Table 1.

Standard curve for the PAG-1 kit was obtained in straight line $\left(\mathrm{R}^{2}=0.979\right)$ with $\mathrm{y}=0.006 \mathrm{x}+0.163$ equation, where $\mathrm{x}$-axis represents the concentration of PAG-1 and y-axis represents respective $\mathrm{OD}_{450}$. The mean concentration of serum PAG-1 in two pregnant groups viz., $30-35 \mathrm{D}$ and 45-50D were $17.28 \pm 2.70$ and $16.58 \pm 3.19 \mathrm{ng} / \mathrm{ml}$, respectively. Lowest PAG-1 concentration $1.0 \mathrm{ng} / \mathrm{ml}$ was reported in group $45-50 \mathrm{D}$, while $30-35 \mathrm{D}$ group showed highest concentration $(38.67 \mathrm{ng} / \mathrm{ml})$. Standard curve for the PSP-B kit was obtained in straight line $\left(\mathrm{R}^{2}=0.997\right)$ with $y=0.011 x+0.231$ equation, where $x$-axis represents the concentration of PSP-B and $\mathrm{y}$-axis represents respective $\mathrm{OD}_{450}$. The mean concentration of serum PSP-B in two pregnant groups viz., $30-35 \mathrm{D}$ and $45-50 \mathrm{D}$ were $15.23 \pm 1.94$ and $19.92 \pm 2.21 \mathrm{ng} / \mathrm{ml}$, respectively. Both lowest $(0.09 \mathrm{ng} / \mathrm{ml})$ and highest $(30.09 \mathrm{ng} / \mathrm{ml})$ PSP-B concentration was reported in group 30-35D. Linear trend for mean concentration was non-significant $(\mathrm{P}>0.05)$ and mean values showed non-significant difference $(\mathrm{P}>0.05)$ across the groups.

Blood concentrations of PAGs/PSP-B were initially measured by radioimmunoassay (Humblot et al., 1988; Zoli et al., 1992; Szenci et al., 1998), and the results have been compared with those of ultrasonography (Szenci et al., 1995). However, ELISA based assays for PAG/PSP-B became commercially available later (Friedrich et al., 2010). Twenty-two PAG genes have been reported till date and it was observed that all the PAGs are not expressed simultaneously throughout the pregnancy rather some are expressed early while others at the different point of time with the progression of pregnancy (Ushizawa et al., 2004). The wide variation in PAG levels limits PAG testing as a reliable indicator of pregnancy until about 26 to 30

Table 1: Descriptive statistics for serum PAG-1 and PSP-B concentration in serum samples of cattle

\begin{tabular}{lllll}
\hline Variables & \multicolumn{2}{c}{ PAG-1 } & PSP-B \\
\cline { 2 - 5 } & 30-35D & 45-50D & 30-35D & 45-50D \\
\hline Sample Size $(\mathrm{n})$ & 16 & 10 & 16 & 10 \\
Min Conc. $(\mathrm{ng} / \mathrm{ml})$ & 1.17 & 1.00 & 0.09 & 1.86 \\
Max Conc. $(\mathrm{ng} / \mathrm{ml})$ & 38.67 & 30.50 & 30.09 & 28.09 \\
Mean \pm SEM & $17.28 \pm 2.70$ & $16.58 \pm 3.19$ & $15.23 \pm 1.94$ & $19.92 \pm 2.21$ \\
Median & 16.25 & 18.50 & 15.86 & 21.00 \\
SD & 10.80 & 10.10 & 7.74 & 6.99 \\
\hline
\end{tabular}


day post-breeding (Zoli et al., 1992; Humblot, 2001). The concentration of PAGs measured through RIA was recorded 1.0-6.0 ng/ml around 28 to 30 days of gestation (Zoli et al., 1992; Karen et al., 2014; Gajewski et al., 2008), which increased steadily up to day $36(8.0-16.0 \mathrm{ng} / \mathrm{ml})$. Our findings are in accordance with these reports. Green et al. (2005) used homologous ELISA with monoclonal PAG antibodies and reported average concentration of PAG about 8.75 and $12.3 \mathrm{ng} / \mathrm{ml}$ at $4^{\text {th }}$ and $5^{\text {th }}$ week postbreeding, respectively. However, Gajewski et al. (2008) measured PAG concentration in cattle at different stages of pregnancy using RIA and reported $3.47 \mathrm{ng} / \mathrm{ml}$ on 41 day, which is comparatively lower than the value recorded in the present study on $45-50$ day $(16.58 \mathrm{ng} / \mathrm{ml})$ using ELISA kit for PAG-1. The differences in the values as compared to reported ones might be attributed to the period of blood collection, different breeds, method of estimation and type of kits. In addition, individual variation in placental production of different PAG molecules could also be a reason for these variations (Piechotta et al., 2011).

We have recorded very high concentration of PSP-B (15$17 \mathrm{ng} / \mathrm{ml}$ ) around day 30-50 of gestation in contrast to $3 \mathrm{ng} / \mathrm{ml}$ by earlier report (Sasser et al., 1986). The first blood based PSP-B assay using RIA in ruminants was described by Sasser et al. (1986) and Humblot et al. (1988). Sasser et al. (1986) developed double antibody radioimmunoassay for the serological detection of PSP-B and observed $1 \mathrm{ng} / \mathrm{ml}$ around day 30 sera which increased up to $9 \mathrm{ng} / \mathrm{ml}$ around 90 days of gestation. Present study reported comparative higher value at around 30 to 50 days of gestation, however, our values are subjected to ELISA. Variable affinity of respective antibodies against targeted bio-molecules may be attributed to the recorded variations (Piechotta et al., 2011). In addition, effect of period of blood collection, breed differences, method of estimation and type of kits could not be ruled out.

\section{Serum progesterone}

The mean \pm SEM concentrations of serum progesterone in different pregnant as well as non-pregnant groups of cattle are presented in Table 2. The mean concentration of serum $\mathrm{P}_{4}$ in different pregnant groups viz., 7-10D, 17-20D, 30$35 \mathrm{D}$ and $45-50 \mathrm{D}$ were $4.18 \pm 0.41,7.75 \pm 0.79,9.27 \pm 0.98$ and $10.78 \pm 1.28 \mathrm{ng} / \mathrm{ml}$, respectively, while values for non-pregnant groups viz., Heifer, Non-AI and PP were $0.13 \pm 0.03,1.76 \pm 0.46,1.31 \pm 0.55 \mathrm{ng} / \mathrm{ml}$, respectively. Lowest $\mathrm{P}_{4}$ concentration was observed in heifer group $(0.02$ $\mathrm{ng} / \mathrm{ml}$ ) while $30-35 \mathrm{D}$ group showed highest concentration $(16.37 \mathrm{ng} / \mathrm{ml})$. However, all the non-pregnant groups sera have low level of progesterone. Linear trend for mean concentration was significant $(\mathrm{P}<0.05)$ and mean values showed significant difference $(\mathrm{P}<0.05)$ across the groups.

High levels of progesterone in serum or milk between days 18 to 24 post-insemination forms the basis of establishment of pregnancy in cattle (Shemesh et al., 1973; Sasser and Ruder, 1987). Mean plasma progesterone concentration in pregnant and non-pregnant cows were recorded 3.05.8 and $0.22-2.0 \mathrm{ng} / \mathrm{ml}$, respectively around 19-22 days post-breeding or post-estrus (Shemesh et al., 1973) and we also observed similar trend in both pregnant as well as non-pregnant groups. Progesterone concentration was observed 2.0-6.2 $\mathrm{ng} / \mathrm{ml}$ in non-pregnant cows and pregnant cows showed about $10.0 \mathrm{ng} / \mathrm{ml}$ concentration around day 24 post-conception (Humblot et al., 1988). We observed comparatively lower progesterone level in present study for both the groups. Serum progesterone level in early gestation around $4^{\text {th }}$ week post-conception ranged between 4.7-5.5 ng/ml in dairy cow (Lobago et al., 2009). Further,

Table 2: Descriptive statistics for serum progesterone concentrations in serum samples of cattle

\begin{tabular}{|c|c|c|c|c|c|c|c|}
\hline Variables & 7-10D & 17-20D & 30-35D & 45-50D & Heifer & Non-AI & $\mathbf{P P}$ \\
\hline Sample Size (n) & 11 & 8 & 16 & 10 & 6 & 13 & 13 \\
\hline Min Conc. (ng/ml) & 2.24 & 5.57 & 1.12 & 1.19 & 0.02 & 0.10 & 0.09 \\
\hline Max Conc. (ng/ml) & 6.21 & 11.71 & 16.37 & 14.76 & 0.26 & 4.67 & 6.97 \\
\hline Mean \pm SEM & $4.18 \pm 0.41$ & $7.75 \pm 0.79$ & $9.27 \pm 0.98$ & $10.78 \pm 1.28$ & $0.13 \pm 0.03$ & $1.76 \pm 0.46$ & $1.31 \pm 0.55$ \\
\hline Median & 4.43 & 7.34 & 9.60 & 12.08 & 0.11 & 1.53 & 0.35 \\
\hline $\mathrm{SD}$ & 1.36 & 2.23 & 3.92 & 4.05 & 0.08 & 1.66 & 2.00 \\
\hline
\end{tabular}


mean progesterone concentration was recorded $7.2 \pm 2.2$, $6.6 \pm 2.8,6.6 \pm 2.4,7.8 \pm 3.0$, and $6.0 \pm 3.4 \mathrm{ng} / \mathrm{ml}$ at $26-29,30$ $33,34-37,38-41$ and $42-58$ days of gestation, respectively in dairy cows (Piechotta et al., 2011). However, we have recorded relatively higher level of serum progesterone during the same window. Variations among the findings might be due to the difference in the method of estimation, type of kits, days of blood collection and breeds.

Table 3: Comparative diagnostic performance of all the methods

\begin{tabular}{lllll}
\hline $\begin{array}{l}\text { Diagnostic } \\
\text { parameters }\end{array}$ & PAG-1 & PSP-B & $\mathbf{P}_{4}$ & USG \\
\hline Sn (\%) & 92.31 & 96.15 & 84.44 & 100.00 \\
Sp (\%) & - & - & 90.63 & 100.00 \\
PPV & - & - & 0.93 & 1.00 \\
NPV & - & - & 0.81 & 1.00 \\
Accuracy (\%) & - & - & 87.01 & 100.00 \\
Youden's Index (J) & - & - & 75.07 & 100.00 \\
\hline
\end{tabular}

In another study, serum progesterone level during the first three weeks post-partum period was reported about 0.28$0.75 \mathrm{ng} / \mathrm{ml}$ (Khatti et al., 2017) and our findings showed close agreement to this for PP group of animals. Most of the reports for estimation of progesterone to monitor the pregnancy are milk based (Zaied et al., 1979; Nebel et al., 1987; Kamboj and Prakash, 1993; Simersky et al., 2007; Samsonova et al., 2015). In addition, we did not find much reports showing level of progesterone around day 7 post-breeding in serum samples (Noakes et al., 2009). However, milk progesterone around day 9-10 postconception reported to be around $11.1 \mathrm{ng} / \mathrm{ml}$ in dairy cows (Zaied et al., 1979), which is comparatively higher to the values observed in present study as level of progesterone in milk is known to be higher because of fat content (Noakes et al., 2009).

\section{Diagnostic evaluation}

In this study, all three immunoassay kits viz., PAG-1, PSP-B and $\mathrm{P}_{4}$ showed high rate of sensitivity i.e. $92.31 \%$, $96.15 \%$ and $84.44 \%$, respectively. We could not calculate specificity of PAG-1 and PSP-B kits as the values for non-pregnant samples were not available. However, progesterone kit showed specificity of $90.63 \%$. Positive predictive value, negative predictive values, accuracy and
Youden's index for $\mathrm{P}_{4}$ kit were $0.93,0.81,87.01$ and 75.07, respectively. These diagnostic parameters could not be calculated for other two immunoassay kits.

The sensitivity of tests reported in this study for PAG-1 (92.31\%), PSP-B (96.15\%) and progesterone (84.44\%) is comparable to previous reports (Romano and Larson, 2010; Piechotta et al., 2011; Sah et al., 2017; Northop et al., 2019; Masello et al., 2020) which also showed about 90 to $97 \%$ sensitivity around fourth week of pregnancy. Specificity of progesterone estimation was observed highest $(90.63 \%)$ as compared to the earlier studies i.e. $57 \%$ by Sah et al. (2017) and $83 \%$ by Masello et al. (2020). Sah et al. (2017) reported 80\% accuracy for serum progesterone estimation through ELISA kit, while present study reported about $87 \%$ using RIA kit in dairy cow. Muhammad et al. (2000) reported $71.4 \%$ and $100 \%$ accuracy for positive and negative samples, respectively for estimation of blood plasma progesterone in Holstein cows. Further, Masello et al. (2020) reported $85 \%$ and 96\% PPV and NPV, respectively. However, we have reported $93 \%$ and $81 \% \mathrm{PPV}$ and NPV, respectively. All these differences in recorded values might be attributed to the different method of detection, variation in sample size, days of blood collection, type of kits used and breed of animals.

\section{CONCLUSION}

All three immunoassays kits based on estimation of biomarkers of pregnancy showed comparable sensitivity to screen the pregnant cow. Diagnostic performance (PPV, NPV and Accuracy) of progesterone kit was relatively better for identification of pregnant and nonpregnant cows. However, lack of values for PSP-B/ PAG-1 in non-pregnant animals limits full reflection of diagnostic performance of respective kits. Henceforth, it is recommended to include large number of pregnant as well as non-pregnant animals to conclude comprehensively on the diagnostic performance of these assays.

\section{ACKNOWLEDGEMENTS}

Authors are thankful to the DBT, New Delhi for financial support for conducting research under the project No. BT/ PR 23570/AAQ/1/691/2017. 


\section{REFERENCES}

Ayad, A., Sousa, N. M., Sulon, J., Iguer-Ouada, M. and Beckers, J.F. 2007. Comparison of five radioimmunoassay systems for PAG measurement: ability to detect early pregnancy in cows. Reprod. Domest. Anim. 42(4): 433-440.

Butler, J.E., Hamilton, W. C., Sasser, R. G., Ruder, C. A., Hass, G. M. and Williams, R. J. 1982. Detection and partial characterization of two bovine pregnancy-specific proteins. Biol. Reprod., 26(5): 925-933.

Commun, L., Velek, K., Barbry, J.B., Pun, S., Rice, A., Mestek, A., Egli, C. and Leterme, S. 2016. Detection of pregnancyassociated glycoproteins in milk and blood as a test for early pregnancy in dairy cows. J. Vet. Diagn. Invest. 28(3): 207213.

Eckblad, W.P., Sasser, R.G., Ruder, C.A., Panlasigui, O.P. M. and Kuczynski, T.S. 1985. Localization of pregnancyspecific protein B (PSPB) in bovine placental cells using a glucose oxidaseanti-glucose oxidase immunohistochemical stain. Proc., West. Sec., Am. Soc. Anim. Sci., 36: 396-397.

Fricke, P.M. 2002. Scanning the future-Ultrasonography as a reproductive management tool for dairy cattle. J. Dairy Sci., 85(8): 1918-1926.

Fricke, P. M., Ricci, A., Giordano, J. O. and Carvalho, P. D. 2016. Methods for and Implementation of Pregnancy Diagnosis in Dairy Cows. Vet. Clin. North Am., 32(1): 165-180.

Friedrich, M. and Holtz, W. 2010. Establishment of an ELISA for measuring bovine pregnancyassociated glycoprotein in serum or milk and its application for early pregnancy detection. Reprod. Dom. Anim., 45: 142-146.

Gabor, G., Toth, F., Ozsvari, L., Abonyi-Toth, Z. and Sasser. R. G. 2007. Early detection of pregnancy and embryonic loss in dairy cattle by ELISA tests. Reprod. Domest. Anim., 42: 633-636.

Gajewski, Z., Sousa, N.M., Beckers, J.F., Pawlinski, B., Olszewska, M., Thun, R. and Kleczkowski, M. 2008. Concentrat ion of bovine pregnancy associat ed glycoprotein in plasma and milk: its application for pregnancy diagnosis in cows. J. Physiol. Pharmacol., 59(Suppl 9): 55-64.

Ginther, O. J. 1998. Ultrasonic imaging and animal reproduction: cattle. Book 3., Equiservices Publishing, Cross Plains, WI, pp. 33-37.

Green, J.A., Parks, T.E., Avalle, M.P., Telugu, B.P., McLain, A. L., Peterson, A.J., McMillan, W., Mathialagan, N., Hook, R. R. and Xie, S. 2005. The establishment of an ELISA for the detection of pregnancy-associated glycoproteins (PAGs) in the serum of pregnant cows and heifers. Theriogenology, $\mathbf{6 3}$ : 1481-1503.

Humblot, P. 2001. Use of pregnancy specific proteins and progesterone assays to monitor pregnancy and determine the timing, frequencies and sources of embryonic mortality in ruminants. Theriogenology, 56: 1417-1433.

Humblot, P., Camous, S., Martal, J., Charlery, J., Jeanguyot, N., Thibier, M. and Sasser, R.G. 1988. Pregnancy-specific protein $\mathrm{B}$, progesterone concentrations and embryonic mortality during early pregnancy in dairy cows. Reproduction, 83: 215-223.

Kamboj, M. and Prakash, B.S. 1993. Relationship of progesterone in plasma and whole milk of buffaloes during cyclicity and early pregnancy. Trop. Anim. Health Pro., 25(3): 185-192.

Karen, A., Bajcsy, A.C., Minoia, R., Kovacs, R., Sousa, N. M., Beckers, J.F., Tibold, J., Madl, I. and Szenci, O. 2014. Relationship of progesterone, bovine pregnancyassociated glycoprotein-1 and nitric oxide with late embryonic and early fetal mortalities in dairy cows. J. Reprod. Dev., 60(2): 162167.

Khatti, A., Mehrotra, S., Maurya, V., Singh, G. and Sarkar, M. 2017. Effect of vitamin E, selenium and increased energy allowance on steroids and reproductive performance in transition period of crossbred cattle. Int. J. Livest. Res., 7(12): 43-50

Lobago, F., Bekana, M., Gustafsson, H., Beckers, J.F., Yohannes, G., Aster, Y. and Kindahl, H. 2009. Serum profiles of pregnancy-associated glycoprotein, oestrone sulphate and progesterone during gestation and some factors influencing the profiles in Ethiopian Borana and crossbred cattle. Reprod. Domest. Anim., 44(4): 685-692.

Masello, M., Lu, Z., Erickson, D., Gavalchin, J. and Giordano, J.O. 2020. A lateral flow-based portable platform for determination of reproductive status of cattle. J. Dairy Sci., 103(5): 4743-4753.

Muhammad, F., Sarwar, A., Hayat, C. S. and Anwar, M. I. 2000. Peripheral plasma progesteron concentration during early pregnancy in holstein feiesian cows. Pak. Vet. J., 20: 166168.

Nebel, R.L., Whittier, W.D., Cassell, B.G. and Britt, J.H. 1987. Comparison of on-farm and laboratory milk progesterone assays for identifying errors in detection of estrus and diagnosis of pregnancy. J. Dairy Sci., 70(7): 1471-1476.

Noakes, D.E., Parkinson, T.J. and England, G.C.W. 2009. Veterinary Reproduction $\&$ Obstetrics. $9^{\text {th }}$ Ed., W B Saunders Company, London, pp. 80-111.

Northrop, E. J., Rich, J. J., Rhoades, J. R. and Perry, G. A. 2019. Comparison of two bovine serum pregnancy tests in detection of artificial insemination pregnancies and pregnancy loss in beef cattle. PloS one, 14(1): e0211179.

Piechotta, M., Bollwein, J., Friedrich, M., Heilkenbrinker, T., Passavant, C., Branen, J., Sasser, G., Hoedemaker, M. and Bollwein, H. 2011. Comparison of commercial ELISA blood 
tests for early pregnancy detection in dairy cows. J. Reprod. Develop., 57(1): 72-75.

Rioux, P. and Rajotte, D. 2004. Progesterone in milk: a simple experiment illustrating the estrous cycle and enzyme immunoassay. Adv. Physiol. Educ., 28(2): 64-67.

Reese, S.T., Pereira, M.C., Vasconcelos, J.L.M., Smith, M.F., Green, J.A., Geary, T.W., Peres, R.F.G., Perry, G.A. and Pohler, K.G. 2016. Markers of pregnancy: how early can we detect pregnancies in cattle using pregnancy-associated glycoproteins (PAGs) and microRNAs? Anim. Reprod. 13(3): 200-208.

Romano, J.E. and Larson, J.E. 2010. Accuracy of pregnancy specific protein-B test for early pregnancy diagnosis in dairy cattle. Theriogenology, 74: 932-939.

Sah, A.K., Bastola, R., Pandeya, Y.R., Pathak, L., Acharya, M. P. and Khanal, D.R. 2017. Accuracy of pregnancy diagnosis with commercially available progesterone kit in dairy cows. Nepalese Veterinary Journal, 34: 101-106.

Samsonova, J.V., Safronova, V.A. and Osipov, A.P. 2015. Pretreatment-free lateral flow enzyme immunoassay for progesterone detection in whole cows' milk. Talanta, 132: 685-689.

Sasser, R.G. and Ruder, C.A. 1987. Detection of early pregnancy in domestic ruminants. J. Reprod. Fertil., 34: 261-271.

Sasser, R.G., Ruder, C.A., Ivani, K.A., Butler, J.E. and Hamilton, W.C. 1986. Detection of pregnancy by radioimmunoassay of a novel pregnancy-specific protein in serum of cows and a profile of serum concentrations during gestation. Biol Reprod., 35: 936-942.

Shemesh, M., Ayalon, N. and Lindner, H.R. 1973. Early pregnancy diagnosis based upon plasma progesterone levels in the cow and ewe. J. Anim. Sci., 36(4): 726-729.

Simersky, R., Swaczynova, J., Morris, D.A., Franek, M. and Strnad, M. 2007. Development of an ELISA-based kit for the on-farm determination of progesterone in milk. Vet. Med., 52(1): 19-28.

Szenci, O., Beckers, J.F., Humblot, P., Sulon, J., Sasser, G., Taverne, M.A., Varga, J., Baltusen, R. and Schekk, G. 1998. Comparison of ultrasonography, bovine pregnancy-specific protein $\mathrm{B}$, and bovine pregnancy-associated glycoprotein 1 tests for pregnancy detection in dairy cows. Theriogenology, 50: $77-88$.
Szenci, O., Gyulai, G., Nagy, P., Kovacs, L., Varga, J. and Taverne, M.A. 1995. Effect of uterus position relative to the pelvic inlet on the accuracy of early bovine pregnancy diagnosis by means of ultrasonography. Vet $Q$., 17: 37-39.

Thompson, J.A., Marsh, W.E., Calvin, J.A., Etherington, W.G., Momont, H.W. and Kinsel, M.L. 1994. Pregnancy attrition associated with pregnancy testing by rectal palpation. $J$. Dairy Sci., 77(11): 3382-3387.

Ushizawa, K., Herath, C.B., Kaneyama, K., Shiojima, S., Hirasawa, A., Takahashi, T., Imai, K., Ochiai, K., Tokunaga, T., Tsunoda, Y., Tsujimoto, G. and Kazuyoshi Hashizume, K. 2004. cDNA microarray analysis of bovine embryo gene expression profiles during the pre-implantation period. Reprod. Biol. Endocrinol., 2: 77.

Vasquez, M.I., Horta, A.E.M., Marques, C.C., Sasser, R.G. and Humblot, P. 1995. Levels of bPSPB throughout single and twin pregnancies after AI or transfer of IVM/IVF cattle embryos. Anim. Reprod. Sci., 38: 279-289.

Wooding, F.B. 1992. Current topic: the synepitheliochorial placenta of ruminants: binucleate cell fusions and hormone production. Placenta, 13: 101-113.

Zaied, A.A., Bierschwal, C.J., Elmore, R.G., Youngquist, R. S., Sharp, A.J. and Garverick, H.A. 1979. Concentrations of progesterone in milk as a monitor of early pregnancy diagnosis in dairy cows. Theriogenology, 12(1): 3-11.

Zemjanis, R. 1970. Pregnancy examination. In: Diagnostic and Therapeutic Techniques in Animal Reproduction. $2^{\text {nd }}$ Ed., 29-Baltimore, Williams and Wilkins, pp. 29-46.

Zoli, A.P., Guilbault, L. A., Delahaut, P., Ortiz, W.B. and Beckers, J.F. 1992. Radioimmunoassay of a bovine pregnancy-associated glycoprotein in serum: its application for pregnancy diagnosis. Biol Reprod., 46: 83-92. 